\title{
Calcium Homeostasis in Escherichia coli: Characterization of Mutants and Genome Expression of MG1655
}

\author{
Muhammad Arif, Josh Howard and Louis S Tisa* \\ Department of Molecular, Cellular and Biomedical Sciences, University of New Hampshire, Durham, NH, USA
}

\begin{abstract}
While the role of calcium ions as secondary messengers has been well described in eukaryotic cells, little is known about calcium homeostasis in bacteria at the physiological and molecular levels. Genetic and genomic approaches were used to address calcium regulation and to identify genes (cal) involved in calcium homeostasis. Transposon mutagenesis of Escherichia coli generated several calcium-sensitive mutants that fell into three categories: (i) $\mathrm{Ca}^{2+}$-sensitive chemotaxis mutants, (ii) $\mathrm{Ca}^{2+}$-sensitive cell division mutants, and (iii) $\mathrm{Ca}^{2+}$-sensitive mutants that showed no defects in cell division or chemotaxis. The physiological properties of these $\mathrm{Ca}^{2+}$-sensitive mutants were determined. Besides calcium-sensitivity to $75 \mathrm{~m} M$ calcium, all of the mutants exhibited increased sensitivities to several divalent cations including $\mathrm{Ni}^{2+}, \mathrm{Mg}^{2+}, \mathrm{Mn}^{2+}$, $\mathrm{Co}^{2+}, \mathrm{Zn}^{2+}, \mathrm{Cu}^{2+}$, and $\mathrm{Cd}^{2+}$. To identify the cal gene sequence in the $\mathrm{Ca}^{2+}$-sensitive mutants, the region of the genes fused to the reporter gene (phoA) on the transposon TnphoA was amplified by PCR and sequenced. The sites of the gene fusion for three cal mutants were at the fdoG, gpt and pqi5 genes. The pleiotropic nature for the cal mutations suggested that many genes may be globally regulated by calcium. We then investigated global gene expression patterns of wild-type $E$. coli under calcium-depleted (addition of $10 \mathrm{mM}$ EGTA) and

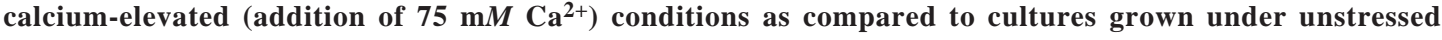
conditions. A comprehensive transcriptome analysis using macroarrys exhibited a global regulation of diverse genes within the $E$. coli genome during calcium homeostasis.
\end{abstract}

Keywords: Calcium, Homeostasis, Escherichia coli, Transposon, Cations, Genome expression profile

\section{Introduction}

Escherichia coli tightly regulate cytosolic free calcium at approximately $100 \mathrm{n} M$, a level similar to that of eukaryotic cells ${ }^{1}$. Calcium ions serve as secondary chemical messengers in eukaryotic cells and tissues including muscle, neural, and cardiovascular tissue. However, the specific role of calcium ions in prokaryotic cells is not as well defined.

The role of calcium ion participation in bacterial behaviour and signal transduction has been established by several lines of evidence $^{2-7}$. Previous studies demonstrate the following observations: (1) Changing cytoplasmic free $\mathrm{Ca}^{2+}$ levels in cells of $E$. coli alters their behavior ${ }^{2}$. Tumbling ensues following the release of free $\mathrm{Ca}^{2+}$ that is produced from caged $\mathrm{Ca}^{2+}$ compounds such as nitr-5 upon irradiation. (2) Changes in bacterial behaviour are correlated with changes in cytoplasmic free $\mathrm{Ca}^{2+}$ level$^{4}$. Fluorescent $\mathrm{Ca}^{2+}$ indicator dye fura-2 was used to show that repellents caused a temporary rise in cytoplasmic free $\mathrm{Ca}^{2+}$ levels, while attractants caused a temporary fall, and the receptor proteins were required for these effects. (3) Some mutants defective in calcium transport have elevated levels of cytoplasmic free $\mathrm{Ca}^{2+}$, tumble continuously, and are defective in chemotaxis ${ }^{3}$. (4) Calcium ion channel blockers inhibit $E$. coli chemotaxis ${ }^{5-6}$.
$\mathrm{Ca}^{2+}$-stimulated kinase activities have been found in E. coli ${ }^{8-10}$ and other bacteria ${ }^{11-12}$. $\mathrm{Ca}^{2+}$-binding proteins and calmodulinlike proteins have been reported to be present in a wide variety of bacteria ${ }^{13}$.Immunological evidence indicates the presence of three calmodulin-like proteins in E. coli, which were suggested to be involved in calcium ion regulation ${ }^{14}$.

The mechanism of calcium entry is unknown. Four genes (calA, calC, calD, and $c h a A$ ) have been identified in $E$. coli that are involved in calcium homeostasis. All three of these loci, A, C, and D, are associated with $\mathrm{Ca}^{2+} / \mathrm{PO}_{4}{ }^{2-}$ symporter activity ${ }^{15}$. The chaA gene is involved in $\mathrm{Ca}^{2+} / \mathrm{H}^{+}$antiporter activity ${ }^{16}$. Recently, ATP has been proposed to regulate calcium efflux in E. coli through an ATPase ${ }^{17}$.

To explore the regulatory role of calcium, we decided to generate calcium homeostasis mutant strains and physiologically characterize the mutant strains. In addition, our efforts included a comprehensive assessment of the genome-wide regulation of calcium homeostasis in E. coli MG1655 wild-type strain to identify candidate calcium homeostasis genes.

\section{Materials and Methods}

Strains, plasmids and phages

All strains of $E$. coli used in this study are derivatives of K12 and are listed in Table 1.

*Corresponding author:

Louis S Tisa, Department of Molecular, Cellular and Biomedical Sciences, University of New Hampshire, Durham, NH, USA.

E-mail: louis.tisa@unh.edu 
Table 1. List of bacterial strains

\begin{tabular}{lll}
\hline Strain & Phenotype & Reference or Source \\
\hline CC118 & araD139 $\triangle$ (ara,leu)7697 $\triangle$ lacX74 phoA & Colin and Beckwith, $1985^{18}$ \\
& $\triangle 20$ galEDgalKthirpsErpoBargEamrecAl & \\
Cal102 & CC118::TnphoA & This study \\
Cal117 & CC118::TnphoA & This study \\
Cal134 & CC118::TnphoA & This study \\
Cal512 & CC118::TnphoA & This study \\
Cal504 & CC118::TnphoA & This study \\
Cal719 & CC118::TnphoA & This study \\
Cal526 & CC118::TnphoA & This study \\
Pho43 & CC118::TnphoA & This study \\
PhoA4 & CC118::TnphoA & This study \\
PhoC23 & CC118::TnphoA & This study \\
MG1655 & Wildtype K12 strain, sequenced first. & Blattneret al., 199719 \\
ëTnphoA & Tn5 IS50L::phoA(KmR) & Guttierrez et al., 198720
\end{tabular}

\section{Growth conditions}

E. coli K12 strain CC118 (ÄphoA, spectinomycin resistant) was the parental strain that was used for mutagenesis and subsequent generation of calcium-sensitive mutants. Cells were grown and maintained in LB medium (1.0\% bactopeptone, $0.5 \% \mathrm{NaCl}, 0.5 \%$ yeast extract) containing the appropriate antibiotics. The calciumsensitive mutants were designated: Cal117, Cal512, Pho43, Cal102, Cal134, PhoA4, PhoC23, Cal504, Cal719, and Cal526. For cation sensitivity assays, cells were grown in $\mathrm{E}$ medium $(0.5 \%$ bactopeptone with $120 \mathrm{mM}$ Tris, $70 \mathrm{mM} \mathrm{NaCl}, 20 \mathrm{mM} \mathrm{KCl,} 20 \mathrm{mM}$ $\mathrm{NH}_{4} \mathrm{Cl}, 3 \mathrm{mMNa}_{2} \mathrm{SO}_{4}, 1 \mathrm{mMMgCl}, 2 \mathrm{ì} \mathrm{ZnCl}$ and $0.4 \%$ glycerol) at a $\mathrm{pH}$ of $7.8^{21}$. For motility and chemotaxis assays, cells were grown in tryptone broth consisting of 1\% Bacto-tryptone and $0.5 \% \mathrm{NaCl}$ and incubated at $35^{\circ} \mathrm{C}$. In some cases, cells were grown in Vogel-Bonner medium ${ }^{22}$ containing the required amino acids at $1 \mathrm{mM}$ and $50 \mathrm{mM}$ glycerol (minimal glycerol medium) or $50 \mathrm{mM}$ DL-lactate (minimal lactate medium).

\section{Transposon TnphoA and mutagenesis of CC118}

The transposon TnphoA was introduced into strain CC118, the parental wild type E. coli strain, by phage ë infection (ë TnphoA) according to the method of Manoil and Beckwith ${ }^{18}$ at a multiplicity of infection (MOI) of 0.05. Cells of strain CC118 were incubated at $37^{\circ} \mathrm{C}$ in $\mathrm{LB}$ medium containing $10 \mathrm{mM} \mathrm{MgSO}_{4}$ and $0.4 \%$ maltose. Overnight grown cells were harvested by centrifugation and resuspended in $10 \mathrm{mM} \mathrm{MgSO}_{4}$. The washed cells were infected with ë TnphoA lysate as described in the next section.

\section{Selection of calcium-sensitive mutants}

For one series, each 100 ìl sample of cells was infected with 10, 100,200 , or $500 \mathrm{il} \mathrm{of} \mathrm{lysate.} \mathrm{The} \mathrm{mixture} \mathrm{was} \mathrm{incubated} \mathrm{at} 30^{\circ} \mathrm{C}$ for $20 \mathrm{~min}$. Following the addition of $1 \mathrm{ml}$ of LB medium, the cells were allowed to outgrow for $30 \mathrm{~min}$ at $30^{\circ} \mathrm{C}$. The cells were harvested by centrifugation at $6,000 \mathrm{x} \mathrm{g}$ for $10 \mathrm{~min}$ and resuspended in E medium containing glycerol (glycerol-E medium). This procedure was repeated twice and the cells were finally resuspended in $1 \mathrm{ml}$ of glycerol-E medium containing 50 $\mathrm{mM} \mathrm{CaCl} 2$ and $60 \mathrm{ìg} / \mathrm{ml}$ kanamycin. Following an incubation at $35^{\circ} \mathrm{C}$ for $1 \mathrm{~h}$, penicillin $\mathrm{G}(15,000 \mathrm{U})$ was added and the cells were allowed to incubate for $3 \mathrm{~h}$. Penicillin G was removed by centrifugation at $6,000 \mathrm{x}$ g for $10 \mathrm{~min}$ and resuspending the cell pellet in glycerol-E medium. This washing step was repeated twice. The cells were finally resuspended in $1 \mathrm{ml}$ of glycerol-E medium and 100-ìl samples were plated on glycerol-E medium plates containing $5 \mathrm{mM} \mathrm{CaCl}_{2}$, 60 ìg/ml kanamycin and $40 \mathrm{ig} / \mathrm{ml} 5$ bromo-4-chloro-3-indolyl phosphate (XP) to screen for TnphoA insertions exhibiting PhoA activity. The plates were incubated at $37^{\circ} \mathrm{C}$ for 2 days before colonies were picked.

For the second series, a 100-ìl sample of cells was infected with 100 -ìl of phage lysate for $20 \mathrm{~min}$ at $37^{\circ} \mathrm{C}$ and directly plated on either (1) glycerol-E medium containing $50 \mathrm{mM} \mathrm{CaCl}$, 30 ìg/ml kanamycin and $40 \mathrm{ig} / \mathrm{ml}$ XP or (2) glycerol-E medium containing 5 $\mathrm{mM} \mathrm{CaCl} 2,180 \mathrm{ìg} / \mathrm{ml}$ kanamycin and $40 \mathrm{ìg} / \mathrm{ml} \mathrm{XP.} \mathrm{These} \mathrm{plates}$ were also incubated at $37^{\circ} \mathrm{C}$ for 2 days before colonies were picked.

Atypically small colonies on the plates were judged to be potential calcium-sensitive mutants. Those colonies that grew on glycerolE medium but not on glycerol-E medium containing $50 \mathrm{mM} \mathrm{CaCl}{ }_{2}$ (thus indicating sensitivity to calcium) were purified and retained.

\section{Calcium-sensitivity assay}

Calcium-sensitivity was later defined as the inability to grow in the presence of $75 \mathrm{mMCaCl}_{2}$. Calcium-sensitivity was measured by two different growth inhibition assays. Initially, calciumsensitivity was measured by growth inhibition assay of Brey and Rosen $^{23}$. Cells were screened for their ability to grow on E medium plates supplemented with $0 \mathrm{mM}, 25 \mathrm{mM}, 50 \mathrm{mM}, 75 \mathrm{mM}$, or 100 $\mathrm{mM} \mathrm{CaCl} 2$. The plates were incubated at $37^{\circ} \mathrm{C}$ and the growth 
results were monitored at $24 \mathrm{~h}$ and $48 \mathrm{~h}$. After $48 \mathrm{~h}$, calciumsensitive cells are unable to grow on $\mathrm{E}$ medium plates supplemented with $75 \mathrm{mM} \mathrm{CaCl} \mathrm{C}_{2}$. Growth inhibition was also determined from turbidity measurements in broth cultures. During this assay, cells were inoculated in E medium broth supplemented with glycerol and different concentrations ( $0 \mathrm{mM}, 25 \mathrm{mM}, 50 \mathrm{mM}$, $75 \mathrm{mM}$, or $100 \mathrm{mM}$ ) of $\mathrm{CaCl}_{2}$, and were incubated at $37^{\circ} \mathrm{C}$ for $8 \mathrm{~h}$. The optical density at a wavelength of $600 \mathrm{~nm}$ was measured at 0 and $8 \mathrm{~h}$.

\section{Cation sensitivity assay}

The sensitivity to various other cations was monitored by growth inhibition assay of the calcium-sensitive cells as described by Brey and Rosen ${ }^{23}$. The minimum inhibitory concentration (MIC) values were determined for each cation tested. MIC is the lowest concentration of cation at which all bacterial growth is stopped.

\section{Chemotaxis assay}

Chemotactic ability was measured by swim-ring migration assay $^{24}$. Tryptone swarm plates containing 1\% bacto-tryptone, $0.5 \% \mathrm{NaCl}$, and $0.25 \%$ bactoagar (Difco Laboratories, Franklin Lakes, New Jersey) were inoculated with a stab of approximately $10^{6}$ cells at the centre of the plates and incubated at $30^{\circ} \mathrm{C}$ for 8 to $14 \mathrm{~h}$. The ring diameters were measured at the end of the experiment.

\section{Analysis of free-swimming behaviour}

Bacterial swimming behaviour was observed at $30^{\circ} \mathrm{C}$ by phasecontrast microscopy at a magnification of 400x. The cells in these behavioural assays were suspended in chemotaxis medium (10 $\mathrm{m} M$ potassium phosphate $\mathrm{pH}$ 7.0, 0.1 $\mathrm{mM}$ potassium EDTA, and $1 \mathrm{~m}$ M L-methionine) or in filtered spent/used growth medium to an optical density at $590 \mathrm{~nm}$ of 0.1 . The microscopic behaviour was videotaped and analyzed by computer ${ }^{25}$.

\section{Alkaline phosphatase assay}

Alkaline phosphatase activity was measured using both solid (for all mutants) and liquid media (only for calcium-sensitive transposon mutant Pho43). Cells were grown at $37^{\circ} \mathrm{C}$ in $\mathrm{LB}$ medium containing appropriate antibiotics. Overnight cultures were then streaked for isolation on $\mathrm{E}$ medium plates containing the chromogenic alkaline phosphatase substrate 5-bromo-4-chloro3-indolyl phosphate (XP). The parental strain CC118 lacks functional alkaline phosphatase. Only colonies that produced alkaline phosphatase fusion on the outside of the cell or in the periplasmic space would turn blue. Following overnight growth at $37^{\circ} \mathrm{C}$, successful calcium-sensitive mutants with functional alkaline phosphatase were monitored for blue color production.

\section{DAPI experiments}

Prior to staining the cells were first fixed with toluene and treated with chloramphenicol to condense their genomes. The fixed cells were incubated with the fluorescent DNA binding dye DAPI (4',6'-diamidino-2-phenylindole $2 \mathrm{HCl}$ ), and observed by the use of phase contrast microscopy and fluorescence microscopy at a total magnification of 1,000x.

\section{Arbitrarily primed PCR}

To identify the $c a l$ gene sequence, the region of the genes fused to the reporter gene ( $p h o A$ ) were amplified by PCR and sequenced. To amplify partial regions of cal genes fused to the transposon, we used the arbitrarily-primed PCR method ${ }^{26-27}$. This method involved two rounds of PCR amplification using arbitrary primers to prime from the chromosome and primers specific to TnphoA. During the first round of PCR, the primer (Tn-R) with sequence homology to the right end of the transposon TnphoA and arbitrary primer ARB1 were used. The PCR parameters for first round were as follows: (1) $95^{\circ} \mathrm{C} 5 \mathrm{~min}$, (2) 6 cycles of $95^{\circ} \mathrm{C}$ for $30 \mathrm{~s}, 30^{\circ} \mathrm{C}$ for 30 $\mathrm{s}, 72^{\circ} \mathrm{C}$ for $1.5 \mathrm{~min}$, (3) 30 cycles of $95^{\circ} \mathrm{C}$ for $30 \mathrm{~s}, 45^{\circ} \mathrm{C}$ for $30 \mathrm{~s}$, and $72^{\circ} \mathrm{C}$ for $2 \mathrm{~min}$. During the second round of PCR, a 5 il aliquot of first round PCR product was used as template and the primers ARB2 and Tn-I were used for amplification.The PCR parameters for second round were as follows: 30 cycles of $95^{\circ} \mathrm{C}$ for $30 \mathrm{~s}, 45^{\circ} \mathrm{C}$ for $30 \mathrm{~s}, 72^{\circ} \mathrm{C}$ for $2 \mathrm{~min}$. The final PCR products were purified from an agarose gel with the aid of â-agarase.The primers (ARB1, ARB2, Tn-I and Tn-R) used in this experiment are listed in Table 2. These PCR amplified products were sequenced using primers (TnphoA-int and Tn-R) located close to the fusion site on TnphoA. DNA sequence data were analyzed by sequence analysis software DNAStar for Mac.The resultant edited sequences, ORFs present in the edited sequences, as well as translated sequences were used to query the $E$. coli genomicdatabase ${ }^{28}$.

Bacterial growth conditions for DNA macroarray experiments To provide a comprehensive insight into calcium homeostasis, the global expression profiles of wild type E. coli MG 1655 were

Table 2. Primers used in arbitrarily-primed PCR and sequencing reaction

\begin{tabular}{lll}
\hline Primer & Primer sequence (5' $\rightarrow$ 3') & Reference \\
\hline ARB1 & GGCCACGCGTCGACTAGTACNNNNNNNNNNGATAT & This study \\
ARB2 & GGCCACGCGTCGACTAGTAC & This study \\
Tn-I & CCTTCGGCATAATTACGTGC & This study \\
Tn-R & GCAGTCTGATCACCCGTTAAA & This study \\
TnphoA-int & TTTCCAGAACAGGGCAAAAC & This study \\
TnphoA-F & TGCAAGTTGAAGGTGCGTCAATCG & This study \\
TnphoA-R & ATGAGATGCCCTGCAAGCAATTCG & This study \\
\hline
\end{tabular}


determined under three different conditions: (1) growth medium containing elevated levels of calcium (the addition $75 \mathrm{mM} \mathrm{CaCl}$ ), (2) growth medium containing depleted levels of calcium (the addition of $10 \mathrm{mM}$ EGTA), and (3) growth medium control (untreated). Overnight cultures of E. coli MG 1655 were used to inoculate fresh $\mathrm{E}$ media and the cultures were incubated at $37^{\circ} \mathrm{C}$ with rotary oration. For the array experiments cultures were grown to an $\mathrm{OD}_{600}$ of 0.4 to 0.5 and then either $75 \mathrm{mM}$ calcium or $10 \mathrm{mM}$ EDTA was added. After 30 min of rotary aeration at $37^{\circ} \mathrm{C}$, total RNA was quickly extracted by using QiagenRNeasy kit (Qiagen, Inc., Valencia, CA). Proper precautions were taken to avoid contamination with RNases and a non-denaturing electrophoresis gel was run with the extracted RNA to check the integrity of RNA.

\section{Synthesis of ${ }^{33} \mathrm{P}$-labeled cDNA probe}

Sigma-Genosys Biotechnologies, Inc. had developed commercially available cDNA primers that are specifically designed to preferentially label cDNA from mRNA. These C-terminal primer sets (4,290 ORF-specific C-terminal primers) were used to generate the hybridization probe according to the manufacturers recommendations. As recommended by the manufacturer, ${ }^{33} \mathrm{P}$-ádCTP was used to label the cDNA. The ${ }^{33}$ P-labeled cDNA was purified and unincorporated-labeled nucleotides were removed by the use of Sephadex G-25 gel-filtration spin columns. An estimation of percentage incorporation of ${ }^{33} \mathrm{P}$-dCTP into the cDNA was determined by using a hand-held Geiger counter or by scintillation counts of samples before and after column purification. The labeled cDNA probe was then ready to be used in a hybridization reaction with the Panorama E. coli Gene Arrays (Sigma-Genosys Biotechnologies, Inc.).

\section{Hybridization with panorama E. coli gene array}

Following its preparation and purification, the ${ }^{33} \mathrm{P}$-labeled cDNA was hybridized to the Panorama gene array by the use of roller bottles in a hybridization oven. The hybridization and washing steps were performed according to the protocol specified in Panorama $E$. coli cDNA Labeling and Hybridization Kit. The DNA array blots were rinsed in 2X SSPE (1X SSPE: $0.18 \mathrm{MNaCl}, 10 \mathrm{mMNaH} 2 \mathrm{PO} 4,1$ $\mathrm{mM}$ EDTA, pH 7.7) and pre-hybridized in pre-warmed hybridization solution (5X SSPE, 2\% SDS, 1X Denhardt's reagent, 100 ìg/ml sheared salmon sperm DNA) at $65^{\circ} \mathrm{C}$ for $1 \mathrm{hr}$ at $6 \mathrm{rpm}$. The entire ${ }^{33} \mathrm{P}$-labeled cDNA was first denatured at $95^{\circ} \mathrm{C}$ for $10 \mathrm{~min}$ and then added to $3 \mathrm{ml}$ of hybridization buffer and the blot were hybridized in this solution for $15 \mathrm{~h}$ at $65^{\circ} \mathrm{C}$. After overnight incubation, the blots were washed with buffer (0.5X SSPE, $0.2 \%$ SDS) three times at room temperature. The blots were then washed three more times with pre-warmed $\left(65^{\circ} \mathrm{C}\right)$ buffer in the hybridization oven at $65^{\circ} \mathrm{C}$ for $20 \mathrm{~min}$ at $6 \mathrm{rpm}$. Washed blots were finally air-dried briefly for $5 \mathrm{~min}$ and wrapped in clear plastic food wrap and exposed to a phosphorimager screen (BioRad Laboratories) for $24 \mathrm{~h}$.

Data acquisition by phosphorimaging and analysis of the arrays The gene expression signals were measured by the use of a BioRad PhosphorImager with a Kodak Low Energy Storage Phosphor Screen. Typically, the arrays were exposed overnight to yield quantifiable results. For quantification, imaging screens were scanned at a 50ìm pixel size and analyzed by Quantity One software (Bio-Rad Laboratories, Hercules, CA) based on the spot coordinates. Each gene has two corresponding spots and the pixel density (intensity) of each spot representing each gene in the array was measured and corrected for the background. The average signal of the pair of duplicate spots were subsequently determined and normalized for comparative studies. To standardize the data from experiments the average intensity for each spot was expressed as a percentage of the total of intensities for all of the spots on the DNA array.

\section{Results and Discussion}

Isolation of calcium-sensitive mutants of E. coli by TnphoA mutagenesis

The $7.7 \mathrm{~kb}$ transposon TnphoA contains $\operatorname{Kan}^{\mathrm{r}}$ gene as a selective marker and the reporter gene for alkaline phosphatase $p h o A$ (Figure 1). The transposon, TnphoA, used as a mutagenic agent for generation and isolation of new calcium-sensitive mutants. The reporter gene for alkaline phosphatase $p h o A$ has no promoter or Shine Dalgarno sequences, and is only expressed when the fusion is in-frame. When inserted in frame and in proper orientation, TnphoA will randomly mutagenize bacterial chromosome by disrupting the gene the transposon will insert itself in. In addition, TnphoA will fuse alkaline phosphatase to the amino terminal of the protein product of the disrupted gene. Alkaline phosphatase is functional when it is fused to a signal that promotes the export of the protein to the envelope of the cell (such as periplasmic, outer membrane or cytoplasmic membrane proteins). Our search for calcium sensitive $E$. coli mutants was targeted to membrane protein genes by essentially isolating $p h o A$ gene fusions. Infection of a phoA deletion strain CC118 with ëTnphoA, followed by penicillin enrichment and subsequent screening of blueness of colonies on XP resulted in mutants with TnphoA insertions exhibiting PhoA activity.

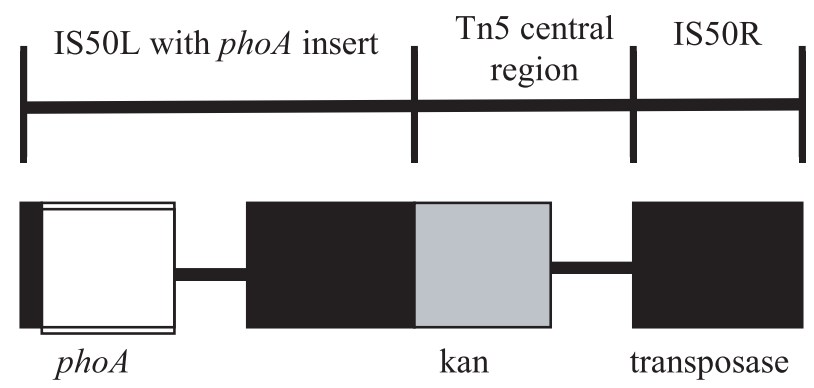

Figure 1. The transposon TnphoA (Manoil and Beckwith ${ }^{18}$ ). The 7.7 Kbp transposon is derived from Tn5 with the selective marker Kan and the reporter gene phoA. Successful (in frame) gene-transposon fusion allows for identification of secreted and transmembrane proteins.

Following transposon mutagenesis, penicillin enrichment was used to aid in the isolation of calcium-sensitive mutants. Several new calcium-sensitive mutants were identified by this transposon mutagenesis procedure. The calcium-sensitive mutants generated are described in Table 1 and photomicrographs of some mutants are included in Figure 2. The mutants fell into three 


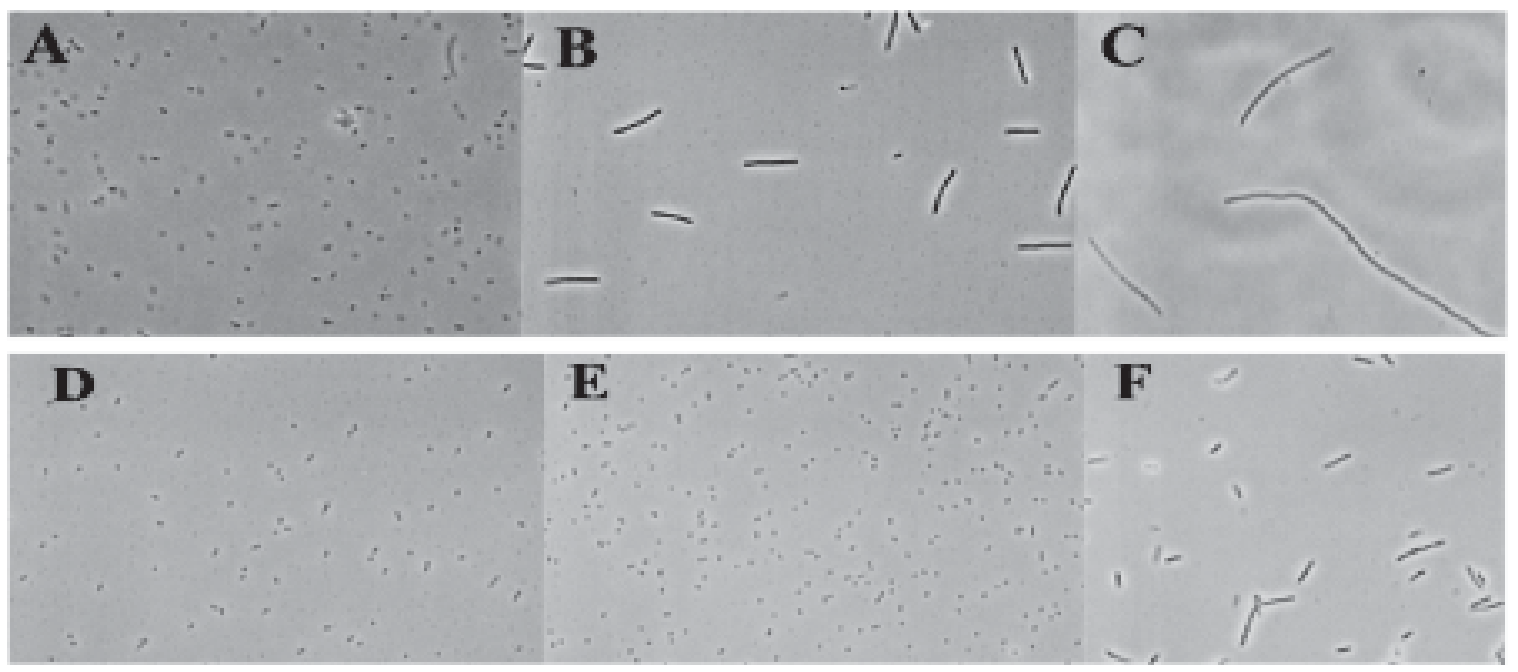

Figure 2. Photomicrograph of wild type Escherichia coli and calcium-sensitive mutants. (A) CC118 with wild type morphology, (B) Cal102 cells with a snake-like morphology consist of up to 10 times the length of the wild type CC118, (C) Cal134 cells were more elongated at about 10 to 20 times the length of CC118, (D) and (E) Cal 117 and Pho43, respectively, had wild type morphology, and (F) Pho43 are long like Cal 102.

general classes: (i) $\mathrm{Ca}^{2+}$-sensitive chemotaxis mutants, (ii) $\mathrm{Ca}^{2+}$ sensitive cell division mutants, and (iii) $\mathrm{Ca}^{2+}$-sensitive mutants that showed no defects in cell division or chemotaxis (Table 3). While some of the mutants were sensitive to $50 \mathrm{mM} \mathrm{CaCl}{ }_{2}$, sensitivity measured by growth inhibition assay revealed the inability of most mutants to grow in the presence of $75 \mathrm{mMCaCl}_{2}$ on plates or in broth cultures.

\section{Physiological and Biochemical Properties of Calcium-Sensitive Mutants}

The cell division mutants (e.g., Cal134) were easily identified microscopically as long "snake-like" cells (Figure 2). One of the $\mathrm{Ca}^{2+}$-sensitive cell division mutants (Cal134) grew as a long filamentous cell that was over 20 cell-body-length in size.

Multiple chromosomes within these snake-like cells were observed following DAPI staining of this mutant (Figure 3). These results imply that this mutant was defective in cell division, but not DNA replication.

The generation of these $\mathrm{Ca}^{2+}$-sensitive cell division mutants was not unexpected. Holland and co-workers ${ }^{29-30}$ isolated mutants that were resistant to different calcium antagonists and are defective in cell division. They proposed a model suggesting that calcium plays a role in the control of bacterial growth and its cell cycle ${ }^{31-32}$. The sensitivity of these calcium-sensitive mutants to other cations was tested and their minimal inhibitory concentration (MIC) values for these cations are shown in Figure 4. Besides calcium-sensitivity, all of the mutants exhibited increased sensitivities to several divalent cations $\left(\mathrm{Ni}^{2+}, \mathrm{Mg}^{2+}\right.$, $\mathrm{Mn}^{2+}, \mathrm{Co}^{2+}, \mathrm{Zn}^{2+}, \mathrm{Cu}^{2+}$, and $\mathrm{Cd}^{2+}$ ). Mutant Cal117 was sensitive to all of the cations tested. Mutants Cal134 and Pho43 exhibited sensitivity to $\mathrm{Co}^{2+}$ and $\mathrm{Zn}^{2+}$, while Cal134 was also sensitive to $\mathrm{Cu}^{2+}$. Cal102 was sensitive to all of the cations except $\mathrm{Ni}^{2+}$, and

Table 3. Properties of calcium-sensitive mutants

\begin{tabular}{lcccc}
\hline Strain & Morphology & Motility & Swim rate mm per 8 hours & Alkaline phosphatase (plate assay) \\
\hline CC118(WT) & Short rods & Smooth-tumbly & 49 & - \\
Cal117 & Medium snakes & Smooth & 0 & ++ \\
Cal512 & Medium snakes & Smooth & 2 & + \\
Cal102 & Medium snakes & Tumbly & 14 & ++ \\
Pho43 & Sausage snakes & Non-motile & 0 & ++ \\
Cal134 & Long snakes & Smooth & 4 & ++ \\
PhoA4 & Short rods & Smooth-tumbly & 37 & +++ \\
PhoC23 & Short rods & Tumbly & 23 & - \\
Cal 719 & Medium snakes & Smooth-tumbly & 31 & ND \\
Cal526 & ND & ND & 11 & ND \\
Cal504 & ND & ND & 12 & ND \\
\hline
\end{tabular}

Medium = 5-8 cell lengths; Long $=10-20$ cell lengths; $-=$ No color; $+=$ Light blue; $++=$ Medium blue; $+++=$ Dark blue; ND $=$ Not determined 

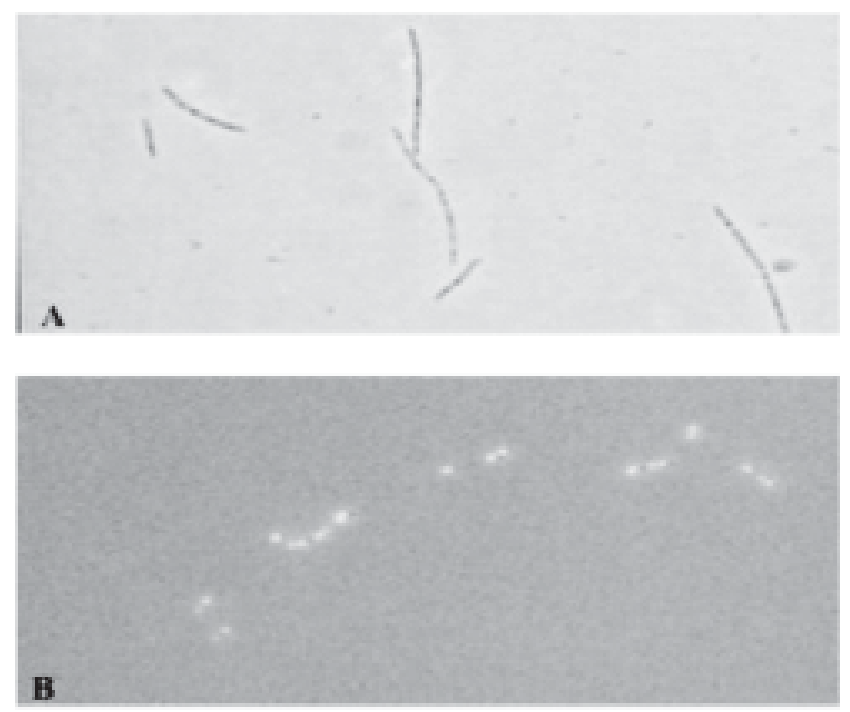

Figure 3. The Cal134 mutant is defective in cell division, but not DNA replication. DAPI stained phase contrast (A) and fluorescent (B) pictures of Cal134 long snake cell division mutants.

Cal512 exhibited a similar pattern of sensitivity as Cal117 though it was not sensitive to $\mathrm{Mn}^{2+}$. It is noteworthy to mention that all calcium-sensitive mutants were resistant to $\mathrm{Mg}^{2+}$ as shown in Figure 4A.

(A) MIC values for cations $(\mathrm{mM})$

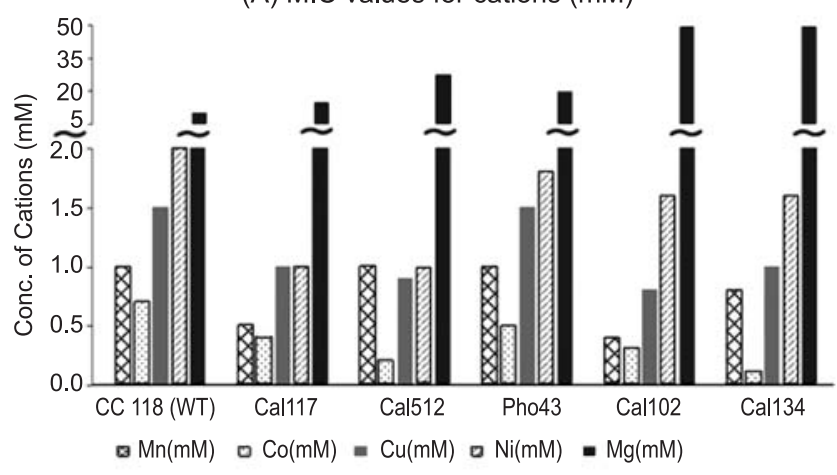

(A) MIC values for $\mathrm{Zn++}(\mu \mathrm{m})$

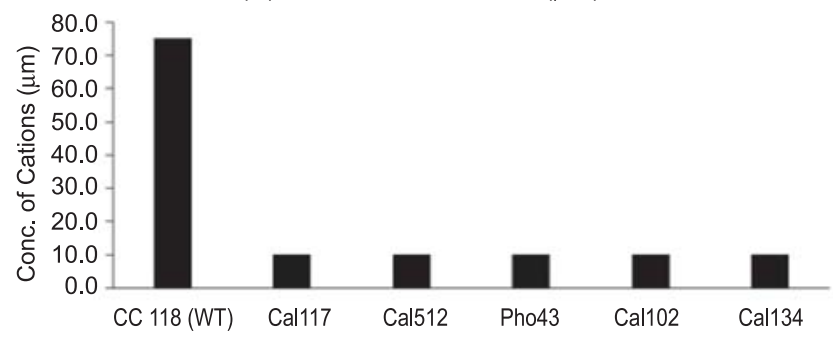

Figure 4. Ca-sensitive mutants were sensitive to other divalent cations. MIC values for cations tested were determined as described in the Methods. Mutants Cal117 and Cal512 exhibit a similar pattern of cation sensitivity (except for $\mathrm{Mg}$ ), while Cal102 and Cal134 exhibit similar profiles. The wild type CC118 and mutant Pho43 have identical MICs for $\mathrm{Mn}^{2+}$ and $\mathrm{Cu}^{2+}$.
In other ion transport systems, mutants defective in ion transport show increased sensitivity to diverse additional ions. $\mathrm{Na}^{+}$ transport mutants are resistant to $\mathrm{Li}^{+3}$, while $\mathrm{Mg}^{2+}$ transport (corA) mutants are resistant to $\mathrm{Co}^{2+}$ and sensitive to $\mathrm{Ca}^{2+34}$. We expected that the cal mutants isolated above would show sensitivities to other cations or that they would show an increased resistance to some cations.

Table 3 summarizes the physiological and biochemical characterization data for a comprehensive representation of observations made on the transposon mutants.

\section{Molecular characterization of calcium-sensitive mutants}

The sites of the gene fusions for three mutants were identified by arbitrarily-primed PCR (arbPCR). Since the PCR products of arbPCR contained part of the upstream regions of the transposon TnphoA fused to the disrupted gene, the start of cal gene was easily recognized. The resulting partial gene sequence was used to search the compiled DNA sequence databank of $E$. coli genome by the use of the BLAST program at NCBI. The sites of the gene fusion for three cal mutants were at the fdoG, gpt and pqi genes (Table 4). The fdoGgene codes for the á-subunit of formate dehydrogenase ${ }^{35}$, while the gpt gene codes for guanine-xanthine phosphoribosyl transferase phosphotransferase ${ }^{36}$ and pqi gene is induced by paraquat and regulated by SoxRS ${ }^{37}$. The arbitrarily-primed PCR fragment of Cal134 exhibited 96\% sequence homology with fdoG gene and also a significant match as evidenced by the e value of 5e-12. Similarly, the cal genes of PhoC23 and PhoA4 showed significant matches to genes gpt and pqiB (e value of 2e-44 and 1e25 , respectively) with $98 \%$ sequence identity for both.

The site of the TnphoA insertion was detected by hybridization of a DIG-labeled TnphoA derived probe to membrane blotted nucleic acids. Hybridization experiments using this TnphoA derived probe confirmed that each mutation was distinct and the result of the single insertion of TnphoA (data not shown). The site of insertion was also confirmed by PCR (data not shown).

The sites of the gene fusion for three cal mutants were the following: gene (Cal134), gpt gene (PhoC23), pqi gene (PhoA4). Our initial observations with the TnphoA-generated cal mutants suggest that their calcium-sensitivity was the result of a number of diverse genes being disrupted by the insertion of the transposon. These results suggest a pleiotropic nature for the cal mutations and indicate that many genes may be regulated by calcium. Because of the results from these experiments, we wanted to investigate global gene expression under growth conditions with and without calcium with a broader goal of identifying all of the calcium-regulated genes in E. coli.

\section{Panorama E. coli gene array}

Panorama E. coli DNA macroarrays (Sigma_Genosys) representing all 4,290 protein-coding genes were used to identify those genes that were globally regulated by calcium and to observe the effects 
Table 4. cal gene mutations identified by ARB-PCR

\begin{tabular}{|c|c|c|c|c|}
\hline Mutant & calgene & Gene function & e-value & \% identity \\
\hline Cal134 & fdoG & $\begin{array}{l}\text { Formate dehydrogenase } \\
\text { (Allows the use of formate as major electron donor } \\
\text { during aerobic respiration) }\end{array}$ & $5 e-12$ & 96 \\
\hline PhoC23 & $g p t$ & $\begin{array}{l}\text { Guanine-hypoxanthine phosphoribosyltransferase } \\
\text { (Involved in salvage of nucleosides and nucleotides) }\end{array}$ & $2 e-44$ & 98 \\
\hline
\end{tabular}

of elevated (75 mM Ca) and depleted calcium (10 mM EGTA) levels on the global transcription profile (Figure 5).

The $23 \mathrm{~S}$ and 16S ribosomal RNA bands were clearly visible at about 2:1 ratio (23S:16S) of staining intensity. The processed RNA samples were devoid of any genomic DNA contamination as evidenced by agarose gel electrophoresis.

The corresponding spots from samples on arrays were compared to identify the fold-induction (up-regulation) or fold-reduction (down-regulation) in expression between the samples (Figure 5). By this method of array analysis a 2-fold difference in expression was considered as important. Changes in expression (fold change) of genes during elevated and depleted calcium conditions are shown in Table 5.

The findings from our study of calcium homeostasis represent a dynamic state with hitherto unknown regulatory activity throughout $E$. coli genome. It is very likely that diverse genes are under calcium regulation as evidenced by changes in gene

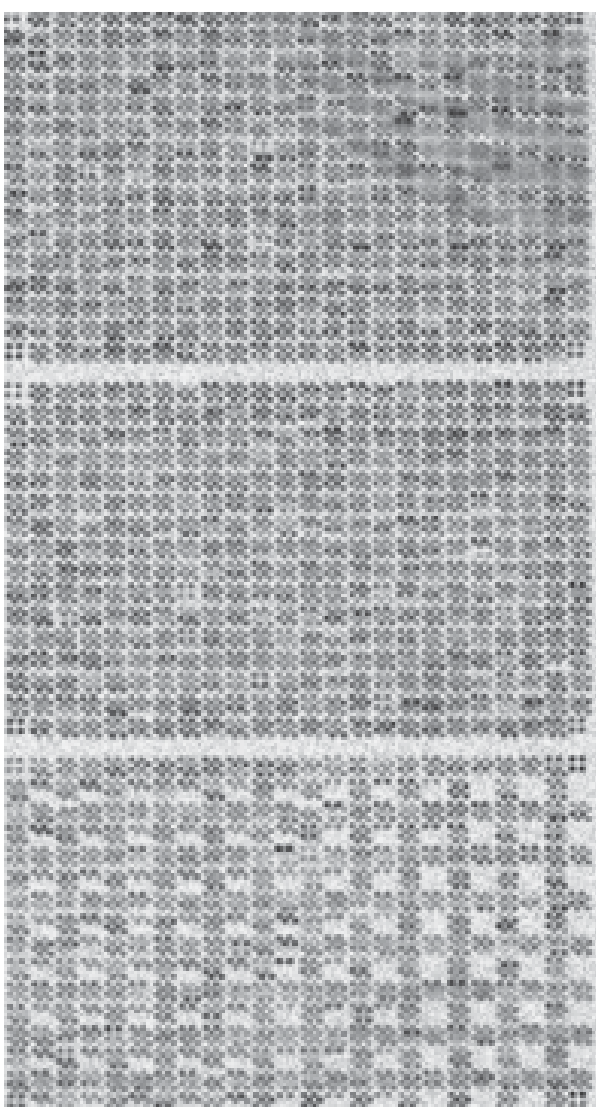

Control

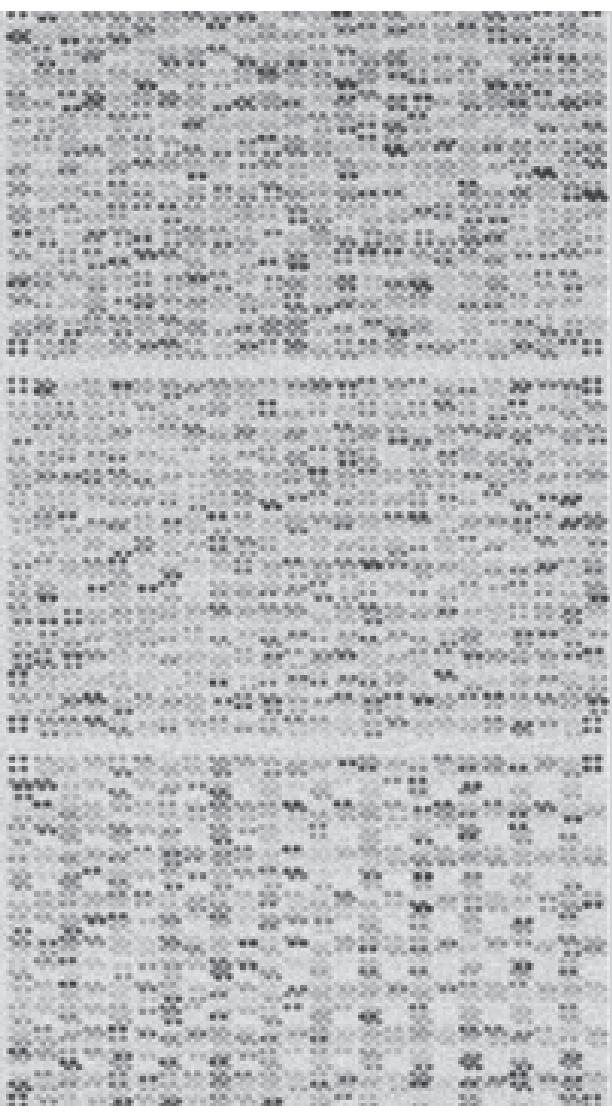

Calcium added

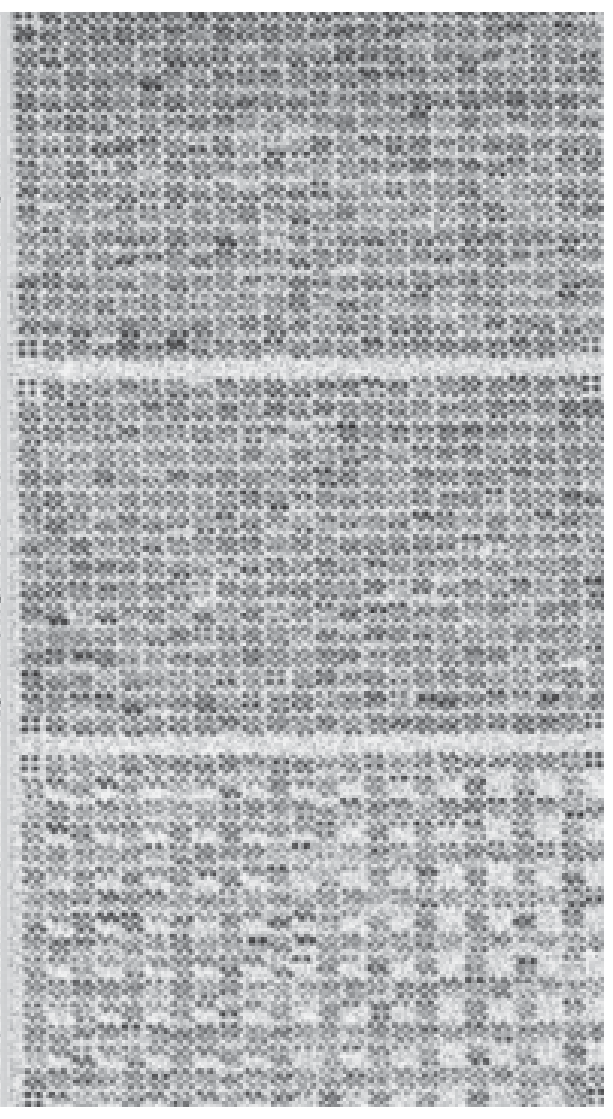

EGTA added

Figure 5. Panorama E. coli gene array exhibiting global gene expression profiles of E. coli MG1655 following growth on E medium (control), E medium supplemented with 75 mM calcium, and E medium supplemented with 10 mM EGTA. 
expression in elevated or depleted calcium. The next logical extension of our study will include an investigation into quantitative analysis of gene expression of subsets of genes in wild-type and mutant strains with addition of calcium and chelation of calcium.

\section{Acknowledgements}

This investigation was supported in part by Grant-in-Aid 96077285 from The American Heart Association and by the College of Life Science and Agriculture, The University of New Hampshire. JH was supported by a Summer Undergraduate Research Fellowship from The University of New Hampshire.

\section{References}

1. Gangola P and Rosen BP. 1987. Maintenance of intracellular calcium in Escherichia coli. J. Biol. Chem. 262: 12570-12574.

2. Tisa LS and Adler J. 1992. Calcium ions are involved in Escherichia coli chemotaxis. Proc Natl Acad Sci USA. 89: 11804-11808.

3. Tisa LS and Adler J. 1995a. Chemotactic properties of Escherichia coli mutants having abnormal $\mathrm{Ca}^{2+}$ content. J. Bacteriol. 177(24): 7112-7118.

4. Tisa LS and Adler J. 1995b. Cytoplasmic free- $\mathrm{Ca}^{2+}$ level rises with repellents and falls with attractants in Escherichia colichemotaxis. Proc Natl Acad Sci USA. 92: 10777-10781.

5. Tisa LS, Olivera B and Adler J. 1993. Inhibition of Escherichia coli chemotaxis by ù-conotoxin, a calcium channel blocker. J Bacteriol. 175: $1235-1238$.

6. Tisa LS, Sekelsky JJ and Adler J. 2000. Effects of organic antagonists of $\mathrm{Ca}^{2+}, \mathrm{Na}^{+}$, and $\mathrm{K}^{+}$on chemotaxis and motility of Escherichia coli. J Bacteriol. 182: 4856-4861.

7. Watkins NJ, Knight MR, Trewavas AJ and Campbell AK. 1995. Free calcium transients in chemotactic and non-chemotactic strains of Escherichia coli determined by using recombinant aequorin. Biochem J. 306: 865-869.

8. Nakashima K, Sigiua A, Momoi H and Mizuno T. 1992. Phosphotransfer signal transduction between two regulatory factors involved in the osmoregulated Kdp operon of Escherichia coli. Mol Microbiol. 6: 1774-1784.

9. Rampersaud A, Utsumi R, Forst SA and Inouye M. 1991. $\mathrm{Ca}^{2+}$ enhanced phosphorylation of a chimeric protein kinase involved with bacterial signal transduction J Biol Chem. 266: 7633-7637

10. Sweeney ST, Freestone P and Norris V. 1995. Characterization of eukaryotic-like kinase activity in Escherichia coli using the geneprotein database. FEMS Microbiol Lett. 127: 133-138.

11. Sandler N and Keynen A. 1992. Membrane-protein phosphorylation in Bacillus subtilis cell cycle. FEMS Microbiol Letts. 95: 241-246.

12. Stowe DJ, Atkinson T and Mann NH. 1989. Protein kinase activities in cell-free extracts of Streptomyces ceolicoler A3(2). Biochimie. 71: $1101-1105$

13. Onek LA and Smith RJ. 1992. Calmodulin and calcium mediated regulation in prokaryotes. J Gen Microbiol. 138: 1039-1049.

14. Laoudi D, Anderson CL, Bras A, Glodberg M, Jacq A and Holland IB. 1994. EGTA induces the synthesis of in Escherichia coli of three proteins that cross-react with calmodulin antibodies. Mol Microbiol. 13: $445-457$.

15. Brey RN and Rosen BP. 1979. Properties of Escherichia coli mutants altered in calcium/proton antiport activity. $J$ Bacteriol. 139: 824-834.

16. Ivey DM, Guffanti AA, Zemsky J, Pinner E, Karpel R, Padan E, Schuldiner S and Krulwich TA. 1993. Cloning and characterization of a putative $\mathrm{Ca}^{2+} / \mathrm{H}^{+}$antiporter gene from Escherichia coli upon functional complementation of $\mathrm{Na}^{+} / \mathrm{H}^{+}$antiporter-deficient strains by the overexpressed gene. J Biol Chem. 268: 11296-11303.
17. Naseem R, Wann KT, Holland IB and Campbell AK. 2009. ATP regulates calcium efflux and growth in E. coli. J Mol Biol. 391: 42-56.

18. Manoil C and Beckwith J. 1985. TnphoA: A transposon probe for protein export signals. Proc Natl Acad Sci USA. 82: 8129-8133.

19. Blattner FR, Plumkett III G, Bloch CA, Perna NT, Burland V, Riley M, Collado-Vides J, Glasner JD, Rode CK, Mayhew GF, Gregor J, Davis NW, Krirkpatrick HA, Goeden MA, Rose DJ, Mau B and Shao Y. 1997. The complete genome sequence of Escherichia coli K-12. Science. 277: 1453-1474.

20. Koh YS and Roe JH. 1995. Isolation of a novel paraquat-inducible (pqi) gene regulated by the soxRS locus in Escherichia coli. J Bacteriol. 177(10): 2673-2678.

21. Brey RN, Beck JC and Rosen BP. 1978. Cation/proton antiport systems in Escherichia coli. Biochem Biophys Res Commun. 83: 1588-1594.

22. Vogel HJ and Bonner DM. 1956. Acetylornithinase of Escherichia coli: Partial purification and some properties. J Biol Chem. 218: 97106.

23. Brey RN and Rosen BP. 1979. Properties of Escherichia coli mutants altered in calcium/proton antiport activity. J Bacteriol. 139: 824834.

24. Adler J. 1966. Effect of amino acids and oxygen on chemotaxis in Escherichia coli. J Bacteriol. 92(1): 121-129.

25. Sager B, Sekelsky JJ, Matsumura P and Adler J. 1988. Use of a computer to assay motility in bacteria. Anal Biochem. 173: 271-277.

26. Caetano-Annoles G. 1993. Amplifying DNA with arbitrary oligonucleotide primers. PCR Methods Appl. 3: 85-92.

27. O’Toole GA and Kolter R. 1998. Initiation of biofilm formation in Pseudomonas fluorescens WCS365 proceeds via multiple, convergent signalling pathways: A genetic analysis. Mol Microbiol. 28: 449-461.

28. Altschul SF, Gish W, Miller W, Myers EW and Lipman DJ. 1990. Basic local alignment search tool. J Mol Biol. 215: 403-410.

29. Bouquin N, Tempête M, Holland IB and Séror S. 1995. Resistance to trifluoroperazine, a calmodulin inhibitor, maps to the $f a b D$ locus in Escherichia coli. Mol Gen Genet. 246: 628-637.

30. Casarégola S, Chen M, Bouquin N, Norris V, Jacq A, Goldberg M, Margarson S, Tempête M, McKenna S, Sweetman H, Bernard S, McGurk G, Séror SJ and Holland IB. 1991. Analysis of a myosin-like protein and the role of calcium in the Escherichia coli cell cycle. Res Microbiol. 142: 201-207.

31. Holland IB, Casaregola S and Norris V. 1990. Cytoskeletal elements and calcium: Do they play a role in the Escherichia coli cell cycle. Res Microbiol.142: 131-137.

32. NorrisV, Seror SJ, Casaregola S and Holland IB. 1988. A single calcium flux triggers chromsome replication, segregation and septation in bacteria: A model. J Ther Biol. 134: 341-350.

33. Park MH, Wong BB and Lusk JE. 1976. Mutants in three genes affecting transport of magnesium in Escherichia coli: Genetics and physiology. J Bacteriol. 126: 1096-1103.

34. Maguire ME. 1993. Genetics and molecular biology of magnesium transport in Salmonella typhimurium. In Magnesium and the Cell (Birch NJ ed), pp 157-178. Academic Press, New York.

35. Wang $\mathrm{H}$ and Gunsalus RP. 2003. Coordinate Regulation of the Escherichia coli formate dehydrogenase $f d n G H I$ and $f d h F$ genes in response to nitrate, nitrite, and formate: Roles for NarL and NarP. $J$ Bacteriol. 185(17): 5076-5085.

36. Pratt D and Subramani S. 1983. Nucleotide sequence of the Escherichia coli xanthine-guanine phosphoribosyltransferase gene. Nucl Acids Res. 11: 8817-8823.

37. Koh YS and Roe JH. 1995. Isolation of a novel paraquat-inducible (pqi) gene regulated by the soxRS locus in Escherichia coli. J Bacteriol. 177(10): 2673-2678. 